\title{
Association between Psoriasis and Chronic Obstructive Pulmonary Disease: A Systematic Review and Meta-analysis
}

\author{
Xin $\mathrm{Li}^{1,2}$, Lingjun Kong ${ }^{3}$, Fulun $\mathrm{Li}^{1}$, Chen Chen ${ }^{2}$, Rong $\mathrm{Xu}^{1}$, Hongshen Wang ${ }^{2}$, \\ Shiguang Peng ${ }^{2}$, Min Zhou ${ }^{1}$, Bin $\mathrm{Li}^{1}{ }^{1}$ \\ 1 Department of Dermatology, Yueyang Hospital of Integrated Traditional Chinese and Western Medicine, \\ Shanghai University of Traditional Chinese Medicine, Shanghai 200437, China, 2 Departmentof \\ Pharmacology\& Experimental Therapeutics, Boston University School of Medicine, Boston, MA 02118, \\ United States of America, 3 Research Institute of Tuina, Shanghai Academy of Traditional Chinese \\ Medicine, Shanghai 201203, China \\ *18930568129@163.com
}

\section{G open access}

Citation: Li X, Kong L, Li F, Chen C, Xu R, Wang H, et al. (2015) Association between Psoriasis and Chronic Obstructive Pulmonary Disease: A Systematic Review and Meta-analysis. PLoS ONE 10(12): e0145221. doi:10.1371/journal.pone.0145221

Editor: Alexander V. Alekseyenko, New York University School of Medicine, UNITED STATES

Received: April 3, 2015

Accepted: November 30, 2015

Published: December 23, 2015

Copyright: $\odot 2015 \mathrm{Li}$ et al. This is an open access article distributed under the terms of the Creative Commons Attribution License, which permits unrestricted use, distribution, and reproduction in any medium, provided the original author and source are credited.

Data Availability Statement: All relevant data are within the paper and its Supporting Information files.

Funding: This work was supported by NSFC of China (nos. 81302971, 81273764 and 81473682); Shanghai Municipal Health Bureau Project (nos. 2010Y133, 2011XY004, XYQ2013073 and ZY3CCCX-3-3033).

Competing Interests: The authors have declared that no competing interests exist.

\section{Abstract}

Psoriasis is considered a systemic inflammatory disorder. Previous studies have reported conflicting positive or negative correlations between psoriasis and chronic obstructive pulmonary disease. We performed a meta-analysis to determine whether there is an associated risk between psoriasis and chronic obstructive pulmonary disease. We performed a complete 30-year literature search of MEDLINE, Embase, and Cochrane Central Register databases on this topic. Four observational studies with a total of 13,418 subjects were identified. The odds ratios of chronic obstructive pulmonary disease in subjects with psoriasis/mild-to-moderate psoriasis were analyzed using the random-effects model, while the odds ratios of chronic obstructive pulmonary disease in subjects with severe psoriasis and current smoking in subjects with psoriasis were analyzed using the fixed-effect model. We found that psoriasis patients were at a greater risk of developing chronic obstructive pulmonary disease than the general population (odds ratio, 1.90; 95\% confidence interval, 1.362.65) and that the association between of psoriasis and with chronic obstructive pulmonary disease was stronger among patients with severe psoriasis (odds ratio, 2.15; 95\% confidence interval, 1.26-3.67). Psoriasis patients should be advised to cease smoking to reduce their risk of COPD. Moreover, identification of this potential risk may enable earlier implementation of preventive measures for reduction comorbidity and mortality rates.

\section{Introduction}

Psoriasis is a common chronic and relapsing immune-mediated inflammatory disease of the skin that affects approximately $2-4 \%$ of the population worldwide[1]. The clinical phenotype of psoriasis may present with several forms, including plaque, guttate, pustular, and erythrodermic. Psoriasis is characterized by scaly and erythematous patches, papules, and plaques that 
can be pruritic, which may result in interrupted sleep, impaired concentration, and an overall reduced quality of life[2]. Although the pathogenesis of psoriasis is not completely understood, a re-evaluation of the recent literature indicated that it is a systemic chronic inflammatory disorder[3]. Since various inflammatory autoimmune diseases result from dysregulation of multiple cytokine pathways [4] including inflammatory cytokines that play key roles across the inflammatory diseases, a variety of disease states could be associated with multiple similar systemic inflammatory cascades[5].

Chronic obstructive pulmonary disease (COPD), which encompasses chronic obstructive bronchitis and emphysema, affects approximately $10 \%$ of the general population[6]. A progressive but not fully reversible airflow limitation and an inflammatory response in the affected lungs leading to dyspnea and other comorbidities characterizes COPD. While COPD is a preventable and treatable but not currently curable disease, a variety of factors associated with an enhanced chronic inflammatory response have been implicated in its pathogenesis, including immune regulation defects, genetic susceptibility, infection, and environmental factors[7]. Smoking being the most important environmental risk factor and key cause of development of $\operatorname{COPD}[8,9]$, the pathogenesis cannot be strictly attributed to a single compound since cigarette smoke contains thousands of injurious agents[10]. Alveolar destruction and airway remodeling results from exposure to chronic cigarette smoke, bombardment by endogenous mediators of inflammation and cell injury[9].

It is widely accepted that common pathogenic mechanisms are shared among many human chronic inflammatory diseases of unrelated pathology and manifestation. Increasing our understanding of the strength of the correlation between psoriasis and COPD will help ensure that future observational studies include adequate adjustments for the presence of COPD among patients with psoriasis. The purpose of this review was to examine the association between psoriasis and COPD using a meta-analysis.

\section{Materials and Methods}

\section{Trial Registration}

The review protocol was registered in the PROSPERO database before the start of the review process (CRD42015025224).

\section{Data sources and searches}

To identify relevant psoriasis studies that included COPD as an outcome measure, three reviewers (X.L., L.J.K., and F.L.L.) systematically searched the MEDLINE, Embase, and Cochrane Central Register databases using the search terms psoriasis, COPD, and chronic obstructive pulmonary disease. Papers published in English and dated between January 1980 and December 2014were included in this study.

\section{Study selection}

To determine eligibility for inclusion in this review, we screened abstracts using the criteria of case-control, cross-sectional, cohort, or nested case-control design studies examining COPD in relation to psoriasis with no limits on participant age, sex, or nationality. The selection criteria for inclusion were as follows: (i) human-only studies; (ii) provision of original data; (iii) inclusion of a reference group; (iv) provision of odds ratios (ORs), risk ratios, or hazard ratio estimates with confidence intervals (CIs) (or enough data to calculate them); or consideration of $\mathrm{COPD}$ as a specific outcome event. 


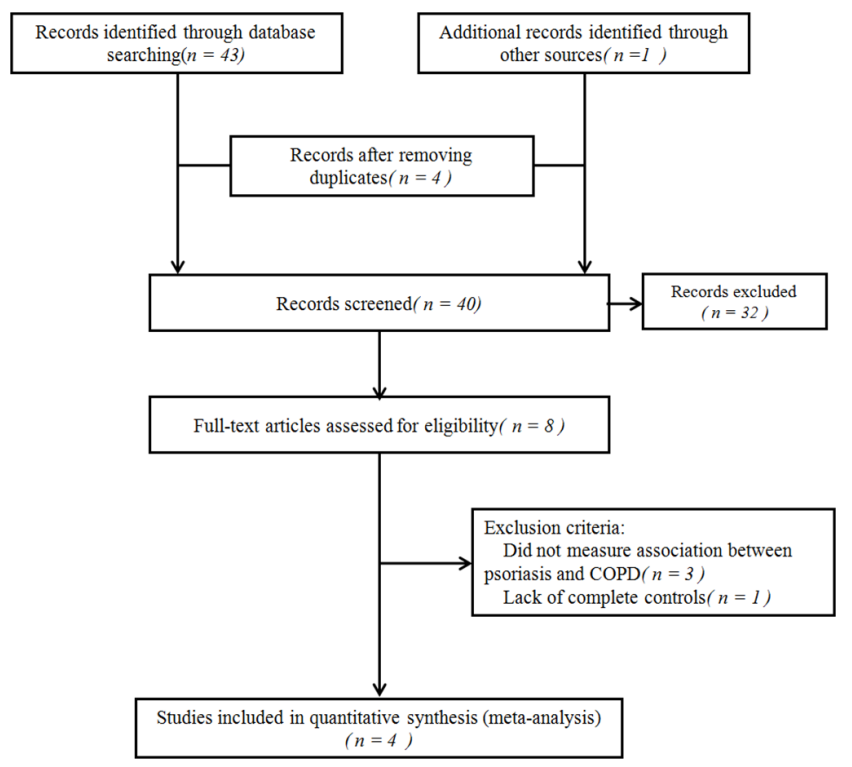

Fig 1. Literature search and study selection.

doi:10.1371/journal.pone.0145221.g001

In this study, we identified 43 articles from the initial search (Fig 1) and through a manual review of the citations from these articles, we found one additional article. After removing four duplicate articles and reading 40 individual abstracts, we identified eight original studies that were eligible for inclusion using the assessment criteria. After a full-text review of these eight studies, we excluded three that did not measure the association between psoriasis and COPD or completely lacked controls. We ultimately selected four studies that met the inclusion criteria for this systematic review[11-14]. The search process is summarized in the flowchart shown in Fig 1.

\section{Data extraction and quality assessment}

Three reviewers independently collected the following descriptive data for each included study:

(i) first author; (ii) study characteristics (year, duration, country, setting, design); (iii) participant characteristics (mean age, numbers of cases and controls, number of patients receiving systemic therapy for psoriasis or COPD, smoking status); and (iv) outcome characteristics (diagnostic criteria of psoriasis).

The Newcastle-Ottawa Scale[15] was used to assess study quality by categorizing it into three dimensions: selection, comparability, and exposure for case-control studies; and selection, comparability, and outcome for cohort studies. The selection, comparability, and exposure dimensions contain four, two, and three items, respectively. A star system was used as a semi quantitative assessment of the study quality. A study was awarded a maximum of one star for each numbered item within the selection and exposure categories. A maximum of two stars were awarded for comparability. The number of stars ranged from zero to nine (high-quality, $\geq 7$ stars; medium-quality, 4-6 stars; poor-quality, $<4$ stars).

\section{Data synthesis and analysis}

The primary outcome was the association of psoriasis with the risk of COPD for each study. The degree of heterogeneity between studies was assessed using $\mathrm{I}^{2}$ tests. An $\mathrm{I}^{2}$ value $>50 \%$ was considered as substantial heterogeneity, and DerSimonian and Laird random-effect models 
were used to compute the globalOR. However, if the inter-study heterogeneity was not substantial $\left(\mathrm{I}^{2}<50 \%\right)$, a fixed-effect model was considered suitable. To investigate possible reasons for heterogeneity, we performed subgroup analysis and meta-regression using pre-specified variables and random-effects meta-analysis. Pre-specified sources of heterogeneity in meta-regression included study location, source population, study design, study quality, severity of psoriasis, psoriatic arthritis included and outcome ascertainment. The methods and findings of this review strictly followed the Meta-analysis of Observational Studies in Epidemiology group guidelines and checklist[16]. The Cochrane Collaboration software Review Manager 5.2 was used for meta-analysis (http://ims.cochrane.org/revman). Meta-regression was performed using STATA version 10.0 (STATA Corp, College Station, TX, USA.).

\section{Results}

Of a total of 44 studies, four observational studies conducted in Europe (one study), Middle East (two studies), and East Asia (one study) in inpatient and outpatient settings, were selected through a systematic review and included in this meta-analysis[11-14]. The four studies included 13,418 participants (3,241 patients with psoriasis, 10,177 controls) who met the inclusion criteria for the dichotomous variables of the systematic review (Table 1). COPD was considered a specific dichotomous outcome event and ORs were provided in all four studies. Three studies reported a statistically significant difference in the incidence of COPD between psoriasis patients and controls[11,13], and all included data on the use of systemic psoriasis treatments[11-13]. More specifically, patients with severe psoriasis received systemic therapy (e.g. phototherapy, psoralen plus ultraviolet A therapy, systemic therapies, or a combination there of), while those with mild psoriasis received topical medication. While two studies included data on COPD drug treatment [12, 13], the other two reported smoking status[12, 14]. Newcastle-Ottawa Scale scores of 4-9 are shown in Table 2. Two studies were deemed of medium quality (4-6stars), while the other two were deemed of high quality ( 7 or $>7$ stars).

The meta-analysis of COPD prevalence in patients with or without psoriasis revealed significant inter-study heterogeneity $\left(\mathrm{I}^{2}=96 \%\right)$. However, low heterogeneity within each separate subgroup (Cohort study $\mathrm{I}^{2}=0 \%$; Case-control study $\mathrm{I}^{2}=27 \%$ ) were displayed. A randomeffects modeling analysis of the pooled data from the four studies showed a significant effect between psoriasis patients and controls on the associated prevalence of COPD (OR, 1.90; 95\% CI, 1.36-2.65) (Fig 2). An optimal subgroup for the Cohort study (OR, 2.53; 95\% CI, 2.442.61) was identified by subgroup analysis. In addition, a significant difference was found between the subgroups from the Case-control study (OR, 1.57; 95\% CI, 1.34-1.82). Metaregression of the association between psoriasis and COPD did not reveal any statistically significant sources of heterogeneity (Table 3).

A meta-analysis of COPD prevalence among mild-to-moderate or severe patients with psoriasis and controls revealed moderate or low inter-study heterogeneity, respectively (mild-tomoderate psoriasis, $\mathrm{I}^{2}=62 \%$; severe psoriasis, $\mathrm{I}^{2}=0 \%$ ), and a significant effect of the associated prevalence of COPD between severe patients and controls (Fig 3). On Random-effects modeling, a significant effect was observed in two studies[11, 12] with a pooled OR of 2.20 (95\% CI, 1.29-3.75). However, no significant effect was found between patients with mild-to-moderate psoriasis and controls using random-effects modeling of the same two studies[11, 12] with a pooled OR of 1.66 (95\% CI, 1.00-2.76) (Fig 3).

The association between psoriasis and the prevalence of smoking addressed in two studies $[12,14]$ showed low inter-study heterogeneity $\left(\mathrm{I}^{2}=9 \%\right)$, while the pooled data showed a significant effect between psoriasis patients and controls in the prevalence of current smoking (OR, 
Table 1. Included Observational Studies.

\begin{tabular}{|c|c|c|c|c|c|c|c|c|c|c|c|}
\hline $\begin{array}{l}\text { Author } \\
\text { (pub. } \\
\text { year) }\end{array}$ & $\begin{array}{l}\text { Study } \\
\text { setting }\end{array}$ & $\begin{array}{l}\text { Study } \\
\text { Period } \\
\text { MM/ } \\
\text { YY-MM/ } \\
\text { YY }\end{array}$ & Study design & Outcome & $\begin{array}{l}\text { Controls: } \\
\text { total } \\
\text { number } \\
\text { and } \\
\text { number } \\
\text { with } \\
\text { COPD } \\
(\%)\end{array}$ & $\begin{array}{l}\text { Cases: } \\
\text { total } \\
\text { number } \\
\text { and } \\
\text { number } \\
\text { with } \\
\text { COPD } \\
(\%)\end{array}$ & $\begin{array}{l}\text { Mean } \\
\text { age of } \\
\text { controls, } \\
\text { years, } \\
\text { mean } \\
\text { (SD) }\end{array}$ & $\begin{array}{l}\text { Mean } \\
\text { age of } \\
\text { cases, } \\
\text { years, } \\
\text { mean } \\
\text { (SD) }\end{array}$ & $\begin{array}{l}\text { Cases } \\
\text { receiving } \\
\text { systemic } \\
\text { therapy } \\
\text { psoriasis }\end{array}$ & $\begin{array}{l}\text { Use of } \\
\text { COPD } \\
\text { drugs (\%) }\end{array}$ & $\begin{array}{l}\text { Smoking } \\
\text { status } \\
(\%)\end{array}$ \\
\hline $\begin{array}{l}\text { Chiang } \\
2012\end{array}$ & $\begin{array}{l}\text { Taiwan; NR } \\
\text { (LHID2005 } \\
\text { and NHID) }\end{array}$ & $\begin{array}{l}01 / \\
2004- \\
12 / \\
2005\end{array}$ & $\begin{array}{l}\text { Retrospective } \\
\text { cohortstudy }\end{array}$ & $\begin{array}{l}\text { Psoriasis } \\
\text { (ICD-9-CM } \\
\text { codes 696.0, } \\
696.1 \text {, and } \\
696.8 \text { ); } \\
\text { COPD (ICD- } \\
9-C M \text { codes } \\
491,492 \text { and } \\
496)\end{array}$ & $\begin{array}{l}\text { Total: } \\
\text { 8342, } \\
\text { COPD: } 42 \\
(0.05)\end{array}$ & $\begin{array}{l}\text { Total: } \\
\text { 2071, } \\
\text { COPD: } \\
\text { 25(1.21); } \\
\text { Mild } \\
\text { psoriasis: } \\
\text { 1580, } \\
\text { COPD } 18 \\
\text { (1.14); } \\
\text { Severe } \\
\text { psoriasis } \\
\text { 491, } \\
\text { COPD } 7 \\
\text { (1.43) }\end{array}$ & $\begin{array}{l}\text { Matched } \\
\text { with } \\
\text { patients } \\
\text { group in } \\
\text { terms of } \\
\text { age (<30, } \\
31-40 \text {, } \\
41-50 \text {, } \\
51-60, \\
61-70, \\
\text { and }>70 \\
\text { years) }\end{array}$ & NR & $\begin{array}{l}\text { Severe- } \\
\text { psoriasis } \\
\text { received } \\
\text { systemic } \\
\text { therapy } \\
\text { (including } \\
\text { phototherapy); } \\
\text { mild-psoriasis } \\
\text { received } \\
\text { topical } \\
\text { medication }\end{array}$ & NR & NR \\
\hline $\begin{array}{l}\text { Wakkee } \\
2011\end{array}$ & $\begin{array}{l}\text { Netherlands; } \\
\text { outpatient/ } \\
\text { inpatient } \\
\text { (PHARMO } \\
\text { Record } \\
\text { Linkage } \\
\text { System) }\end{array}$ & $\begin{array}{l}1997- \\
2008\end{array}$ & $\begin{array}{l}\text { Retrospective } \\
\text { cohort study }\end{array}$ & $\begin{array}{l}\text { International } \\
\text { Classification } \\
\text { of Diseases, } \\
\text { Ninth } \\
\text { Revision, } \\
\text { Clinical } \\
\text { Modification }\end{array}$ & $\begin{array}{l}\text { Total: } \\
\text { 128710, } \\
\text { COPD: } \\
13379 \\
(10.40)\end{array}$ & $\begin{array}{l}\text { Total: } \\
\text { 25742, } \\
\text { COPD: } \\
5834 \\
(22.70)\end{array}$ & $\begin{array}{l}38.2 \\
(22.9)\end{array}$ & $\begin{array}{l}44.3 \\
(19.6)\end{array}$ & $\begin{array}{l}\text { Severe } \\
\text { psoriasis } \\
\text { received } \\
\text { systemic } \\
\text { therapy (i.e., } \\
\text { PUVA therapy, } \\
\text { systemic } \\
\text { therapies, } \\
\text { inpatient } \\
\text { treatment or a } \\
\text { combination of } \\
\text { these) }\end{array}$ & $\begin{array}{l}\text { Psoriasis } \\
\text { cohort: } \\
22.7 ; \\
\text { Reference } \\
\text { cohort: } \\
10.4\end{array}$ & NR \\
\hline $\begin{array}{l}\text { Al- } \\
\text { Mutairi } \\
2010\end{array}$ & $\begin{array}{l}\text { Kuwait; } \\
\text { outpatient }\end{array}$ & $\begin{array}{l}01 / \\
2003- \\
12 / \\
2007\end{array}$ & $\begin{array}{l}\text { Retrospective } \\
\text { case-control } \\
\text { study }\end{array}$ & NR & $\begin{array}{l}\text { Total: } \\
\text { 1835, } \\
\text { COPD: } 74 \\
(4.03)\end{array}$ & $\begin{array}{l}\text { Total: } \\
\text { 1835, } \\
\text { COPD: } \\
\text { 98(5.34); } \\
\text { Mild- } \\
\text { moderate } \\
\text { psoriasis: } \\
\text { 1661, } \\
\text { COPD } 89 \\
\text { (5.36); } \\
\text { Severe } \\
\text { psoriasis } \\
\text { 129, } \\
\text { COPD } 9 \\
\text { (6.98) }\end{array}$ & $\begin{array}{l}52.7 \\
(13.5)\end{array}$ & $\begin{array}{l}52.3 \\
(11.9)\end{array}$ & $\begin{array}{l}\text { Psoriasis } \\
\text { received } \\
\text { significantly } \\
\text { wider varieties } \\
\text { of systemic } \\
\text { drugs }\end{array}$ & $\begin{array}{l}\text { Psoriasis: } \\
4.3 ; \\
\text { Control: } \\
3.8\end{array}$ & $\begin{array}{l}\text { Current } \\
\text { smoker } \\
\text { Psoriasis: } \\
\text { 51.34; } \\
\text { Control: } \\
\text { 32.5; Ex- } \\
\text { smoker } \\
\text { Psoriasis: } \\
22.98 ; \\
\text { Control: } \\
\text { 15.51 }\end{array}$ \\
\hline $\begin{array}{l}\text { Dreiher } \\
2008\end{array}$ & $\begin{array}{l}\text { Israel; NR } \\
\text { (CHS) }\end{array}$ & NR & $\begin{array}{l}\text { Retrospective } \\
\text { case-control } \\
\text { study }\end{array}$ & $\begin{array}{l}\text { The } \\
\text { diagnoses of } \\
\text { COPD was } \\
\text { taken from } \\
\text { the CHS } \\
\text { chronic } \\
\text { diseases } \\
\text { registry }\end{array}$ & $\begin{array}{l}\text { Total: } \\
\text { 24287, } \\
\text { COPD: } \\
873(3.60)\end{array}$ & $\begin{array}{l}\text { Total: } \\
\text { 12502, } \\
\text { COPD: } \\
716(5.70)\end{array}$ & $\begin{array}{l}54.3 \\
(17.5)\end{array}$ & $\begin{array}{l}55.8 \\
(16.7)\end{array}$ & NR & NR & $\begin{array}{l}\text { Current } \\
\text { smoker } \\
\text { Psoriasis: } \\
12.5 ; \\
\text { Control: } \\
9.6\end{array}$ \\
\hline
\end{tabular}

LHID, longitudinal health insurance database; NHID, national health insurance database; NR, not reported; PUVA, psoralen plus ultraviolet A 
Table 2. Newcastle-Ottawa Scale (NOS) Quality Assessment Table.

\begin{tabular}{|c|c|c|c|c|}
\hline Study & Selection & Comparability & Exposure/outcome & Overall star rating \\
\hline Chiang 2012 & ++++ & ++ & ++ & 8 \\
\hline Wakkee 2011 & +++ & & ++ & 5 \\
\hline Al-Mutairi 2010 & +++ & ++ & ++ & 7 \\
\hline Dreiher 2008 & ++++ & & ++ & 6 \\
\hline
\end{tabular}

A star system was used for allow a semi quantitative assessment of study quality. A study was awarded a maximum of one star for each numbered item within the selection and exposure categories. A maximum of two stars were awarded for comparability. The NOS ranges from zero to nine stars. We considered high-quality studies as those that achieved seven or more stars, medium-quality studies those with four to six stars, and poor-quality studies those with fewer than four stars.

doi:10.1371/journal.pone.0145221.t002

2.05; 95\% CI, 1.85-2.28) (Fig 4). Regrettably, we could not confirm a direct association between smoking and COPD in patients with psoriasis.

\section{Discussion}

Our results demonstrated that psoriasis patients are at a greater risk of developing COPD (OR, $1.90 ; 95 \% \mathrm{CI}, 1.36-2.65)$, and the association was stronger in patients with severe psoriasis (OR, 2.15; 95\% CI, 1.26-3.67).

This study collected and reanalyzed individual participant data including a total of 13,418 participants from four observational studies for the effects of psoriasis on the incidence of COPD. These studies provide almost all of the available epidemiological evidence worldwide on the topic. Since the 1980s, only five studies[11-14,17] have been conducted to investigate the possible correlation between psoriasis and COPD. A previous study observed a higher prevalence of COPD (5.0\%) than expected based on the total U.S. population data (1.7\%) in 2005

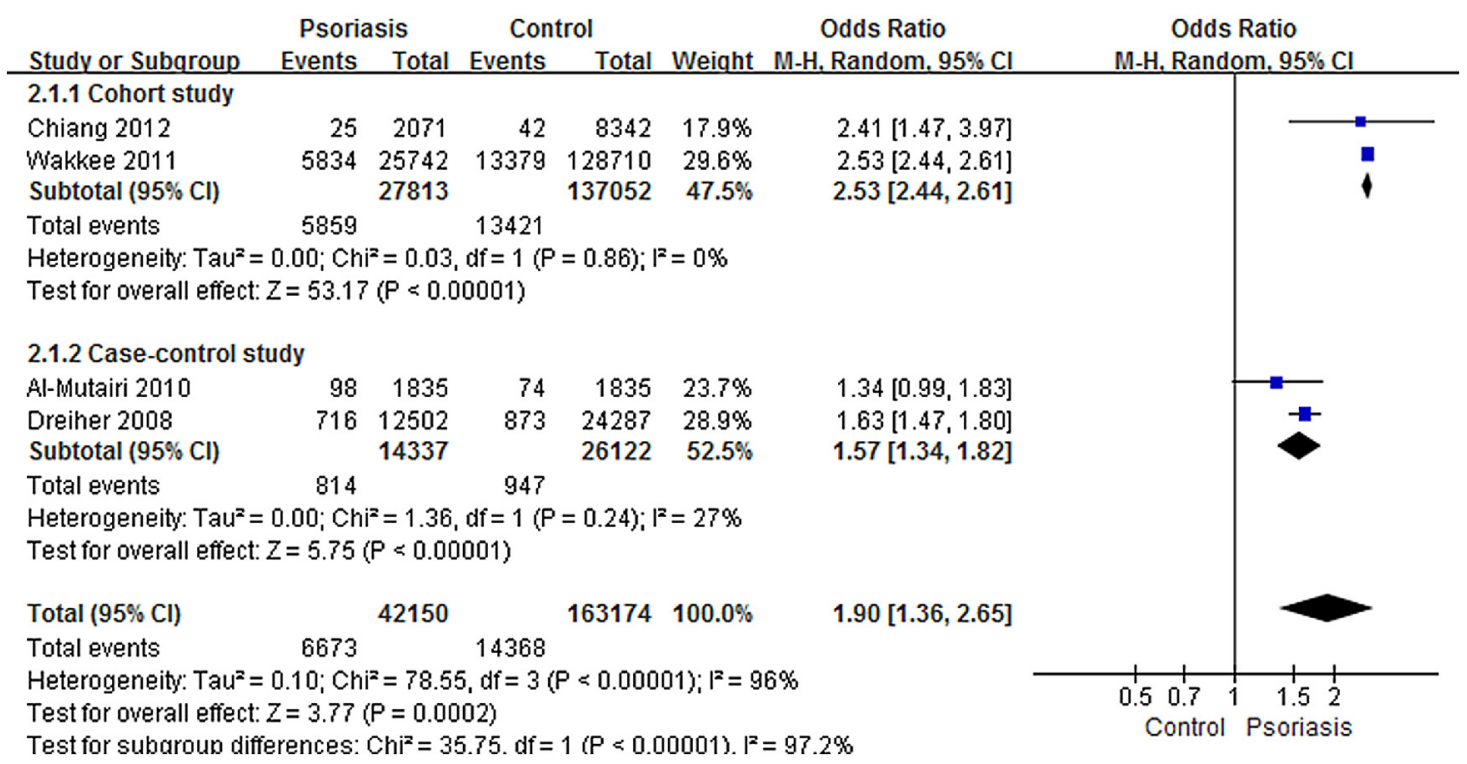

Fig 2. Meta-analysis of the prevalence of chronic obstructive pulmonary disease (COPD) in patients with psoriasis compared with controls. "Events" means the number of COPD in subjects. Odds ratios (ORs) for COPD in subjects with psoriasis compared with subjects without psoriasis. The point estimate (center of each blue square) and the statistical size (proportional area of the square) are shown. Horizontal lines indicate $95 \%$ confidence intervals. The pooled OR (diamond) was calculated using a random effects model.

doi:10.1371/journal.pone.0145221.g002 
Table 3. Potential prespecified sources of heterogeneity explored among studies reportingan association between psoriasis and COPD.

\begin{tabular}{|c|c|c|c|}
\hline Prespecified source of heterogeneity & No. of studies & Random-effects meta-regression $(95 \% \mathrm{Cl})$ & P-value \\
\hline Study location & & & 0.240 \\
\hline Europe & 1 & $0.025(1.144-2.118)$ & \\
\hline Asia & 3 & $0.025(1.069-1.455)$ & \\
\hline Other & 0 & $\mathrm{~N} / \mathrm{A}$ & \\
\hline Source population & & & 0.454 \\
\hline Inpatient & 0 & $\mathrm{~N} / \mathrm{A}$ & \\
\hline Outpatient & 1 & $0.312(0.150-2.704)$ & \\
\hline No distinction & 3 & $0.312(0.370-6.665)$ & \\
\hline Study design & & & 0.360 \\
\hline Case-control & 2 & $0.013(0.506-0.792)$ & \\
\hline Cohort & 2 & $0.013(1.262-1.976)$ & \\
\hline Study quality & & & 0.630 \\
\hline High-quality( $\geq 7$ stars $)$ & 2 & $0.700(0.180-4.023)$ & \\
\hline Medium-quality(4-6stars) & 2 & $0.700(0.249-5.545)$ & \\
\hline poor-quality(<4stars) & 0 & $\mathrm{~N} / \mathrm{A}$ & \\
\hline Severity of psoriasis & & & 0.690 \\
\hline No distinction & 2 & $0.700(0.180-4.023)$ & \\
\hline Mild vs. severe & 2 & $0.700(0.249-5.545)$ & \\
\hline Psoriatic arthritis included & & & 1.000 \\
\hline No & 0 & $\mathrm{~N} / \mathrm{A}$ & \\
\hline Yes & 2 & $0.985(0.193-5.109)$ & \\
\hline Not clear & 2 & $0.985(0.196-5.191)$ & \\
\hline Outcome ascertainment & & & 0.500 \\
\hline Billing data & 1 & $0.312(0.150-2.704)$ & \\
\hline Chart review & 3 & $0.312(0.370-6.665)$ & \\
\hline Examination & 0 & N/A & \\
\hline
\end{tabular}

$\mathrm{Cl}$, confidence interval; N/A, not applicable.

doi:10.1371/journal.pone.0145221.t003

[17]. Moreover, the results of a large, population-based case-control study further supported the association between psoriasis and COPD, and suggested smoking cessation as a COPD risk-reduction strategy in patients with psoriasis[14], although whether the correlation between smoking and COPD events is circumstantial or causal in psoriasis patients remains to be answered. In contrast[12], a case-control study conducted in the Middle East provided conflicting results. Therefore, since the association between psoriasis and COPD remains unclear and controversial among clinicians, a meta-analysis study was needed to further examine the correlation between psoriasis and COPD.

The consistent association between psoriasis and COPD suggests a likely pathophysiologic link between the two diseases. The hypothesis of a common cytokine-based pathology, wherein one inflammatory autoimmune disease significantly increased the risk of another, is gradually being accepted[18]. It is believed that the inflammatory response in psoriasis leads to a Th1 lymphocyte cytokine milieu with increased levels of IL-1, IL-6, IL-8, TNF- $\alpha$, and markers of systemic inflammation [3, 19]. Similarly, elevated levels of these pro-inflammatory cytokines have also been found in the sputum and bronchoalveolar lavage of COPD patients[20, 21]. Specifically, the $\mathrm{T}$ cell receptor and co-stimulatory molecules (e.g. CD3, CD8)[3, 22, 23]; T cell cytokines (e.g. interferon- $\gamma$, IL-13, IL-17, IL-23) [3, 21, 24, 25]; other pro-inflammatory 


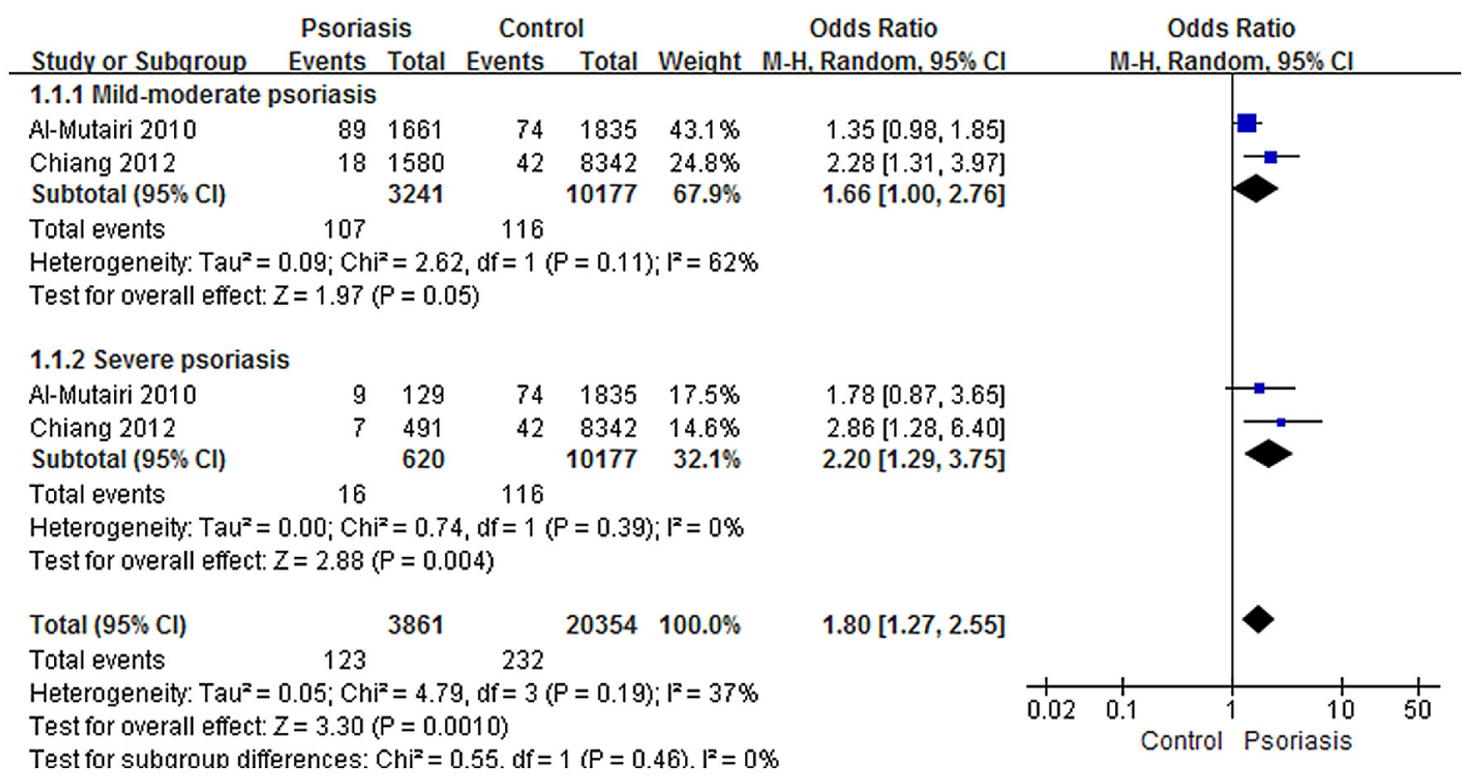

Fig 3. Meta-analysis of the prevalence of chronic obstructive pulmonary disease (COPD) in patients with mild to moderate or severe psoriasis compared with controls. "Events" means the number of COPD in subjects. Odds ratios (ORs) for COPD in subjects with psoriasis compared to subjects without psoriasis. The point estimate (center of each blue square) and the statistical size (proportional area of the square) are shown. Horizontal lines indicate 95\% confidence intervals. The pooled ORs (diamond) were calculated using random effects model.

doi:10.1371/journal.pone.0145221.g003

cytokines (e.g. TGF- $\beta$, IL-12, IL-18,IL-22)[3, 21, 25-28]; chemokines and receptors (e.g. CXCR1, CXCR2, CXCR3) [3, 21, 29]; adhesion molecules (e.g. ICAM-1, E-selectin, CD18)[21, 30,31]; and proteases (elastase, cathepsins, and matrix metalloproteinases)[21, 32, 33] have all been implicated in the pathogenesis of psoriasis and COPD. These cellular subpopulations and mediators are often excellent targets for monoclonal antibodies or biologics, while several monoclonal antibodies and/or biological reagents have been developed confirm the existence of common molecular targets in clinical studies, including an anti-IL8 antibody (ABX-IL-8) [34], CXCR2 (danirixin)[35], and phosphodiesterase 4 inhibitors (roflumilast)[36, 37], and TNF- $\alpha$ antagonists (etanercept). The fact that similar immunotherapeutic agents have been developed for the treatment of psoriasis and COPD provides further indirect evidence of the close connection between the two diseases.

It is interesting that the pooled OR of the associated prevalence of COPD between the patients with severe psoriasis and controls was significant compared to those with mild-to-

\begin{tabular}{|c|c|c|c|c|c|c|c|c|}
\hline \multirow[b]{2}{*}{ Study or Subqroup } & \multicolumn{2}{|c|}{ Psoriasis } & \multicolumn{2}{|c|}{ Control } & \multirow{2}{*}{\multicolumn{2}{|c|}{$\begin{array}{cc} & \text { Odds Ratio } \\
\text { Weight } & \text { M-H, Fixed, 95\% Cl }\end{array}$}} & \multirow{2}{*}{\multicolumn{2}{|c|}{$\begin{array}{c}\text { Odds Ratio } \\
\text { M-H, Fixed, } 95 \% \mathrm{Cl}\end{array}$}} \\
\hline & Events & Total & Events & Total & & & & \\
\hline Al-Mutairi 2010 & 762 & 1484 & 371 & 1141 & $41.1 \%$ & $2.19[1.87,2.57]$ & & \\
\hline Dreiher 2008 & 443 & 12502 & 447 & 24287 & $58.9 \%$ & $1.96[1.71,2.24]$ & & \\
\hline Total $(95 \% \mathrm{Cl})$ & & 13986 & & 25428 & $100.0 \%$ & $2.05[1.85,2.28]$ & & \\
\hline Total events & 1205 & & 818 & & & & & \\
\hline $\begin{array}{l}\text { Heterogeneity: } \mathrm{Chi}^{2}= \\
\text { Test for overall effec }\end{array}$ & $\begin{array}{l}1.10, \mathrm{df}= \\
Z=13.78\end{array}$ & $\begin{array}{l}1(P=0 \\
(P<0.0\end{array}$ & $\begin{array}{l}\text { 29); } F= \\
0001)\end{array}$ & & & & $\begin{array}{cc}1 & 1 \\
0.5 & 0.7 \\
& \text { Contro }\end{array}$ & $\begin{array}{l}1.52 \\
1 \\
\text { Psoriasis }\end{array}$ \\
\hline
\end{tabular}

Fig 4. Meta-analysis of psoriasis and prevalence of current smoking compared with controls. "Events" means the number of current smoking in subjects. Odds ratios (ORs) for current smoking in subjects with psoriasis compared with subjects without psoriasis. The point estimate (center of each blue square) and the statistical size (proportional area of the square) are shown. Horizontal lines indicate $95 \%$ confidence intervals. The pooled OR (diamond) was calculated using a fixed-effects model.

doi:10.1371/journal.pone.0145221.g004 
moderate psoriasis. Likewise, psoriasis confers an increased risk of developing cardiovascular and ischemic heart disease; only severe psoriasis has been reported as an independent cardiovascular risk factor[38]. Unsurprisingly, cigarette smoking, the most important environmental risk factor involved in the development of COPD[8], has been proposed as an independent risk factor for the development of psoriasis[39]; this is also supported by the findings of the present study.

This study has several strengths. We performed a careful meta-analysis using three different data sources. Multiple authors reviewed the data independently, thereby minimizing the risk of publication bias or missing data. By separating prevalence in the analysis, as well as the severity of psoriasis, we were able to better quantify the possible temporal association between psoriasis and COPD. We also performed meta-regression analyses to identify sources of heterogeneity that commonly occur during meta-analyses of observational data. While conducting this study, we were fully aware of several well-documented limitations, including the distorting effects that publication and location bias may have on systematic reviews and metaanalyses[40]. Only four observational studies from Europe, Middle East, and East Asia were eligible and reviewed, although we were confident that our search strategy located all relevant studies, a certain degree of uncertainty persisted. As the included studies did not test the causation, we could not infer a causal relationship between psoriasis and COPD according to the available evidence from primary studies. As all systematic reviews must be interpreted in the context of the available primary studies, the variations in study findings observed here are likely attributable to differences in study design, patient population, and the ascertainment of predictors and outcomes. Ethnic-specific differences in COPD prevalence and severity were identified among genotypes as well as other factors such as genetic-environmental interactions [41].

Meanwhile, COPD is more prevalent in patients of middle and older age: the mean age of participants from the three included studies was 44.3 years, which almost coincides with the COPD onset age[12-14]. However, despite the age- and ethnicity-related factors, the potential heterogeneity among studies and the lack of a significant effect between patients with mild to moderate psoriasis and controls (OR, 1.66; 95\% CI, 1.00-2.76), the directionality of the association between psoriasis and COPD were established. Therefore, patients with psoriasis should receive appropriate information regarding this association and should be advised to cease smoking to reduce their risk of COPD. Future studies to infer a causal relationship should include prospective follow-up studies to explore the mechanisms underlying the association between the two conditions and investigate the role of systemic psoriasis therapies for preventing COPD.

\section{Conclusions}

In summary, patients with psoriasis are at greater risk of developing COPD. The association between psoriasis and COPD was stronger in patients with severe psoriasis. Physicians should be aware of this potential risk to reduce comorbidity and mortality rates. Evidence of the link between psoriasis and COPD is strengthened by the fact that a number of monoclonal antibodies and/or biological reagents currently under clinical development have been designed for use in patients with psoriasis or COPD.

\section{Supporting Information}

S1 MOOSE Checklist. MOOSE checklist.

(DOC) 


\section{Acknowledgments}

We thank Dr. Katherine J. Strissel for her wonderful suggestions and edits.

\section{Author Contributions}

Conceived and designed the experiments: X. Li B. Li. Performed the experiments: X. Li LJK FLL HSW SGP. Analyzed the data: X. Li LJK. Contributed reagents/materials/analysis tools: X. Li LJK FLL. Wrote the paper: X. Li CC B. Li. Study supervision: X. Li and B. Li. Critical revision of the manuscript for important intellectual content: LJK MZ RX.

\section{References}

1. Kurd SK, Gelfand JM. The prevalence of previously diagnosed and undiagnosed psoriasis in US adults: results from NHANES 2003-2004. Journal of the American Academy of Dermatology. 2009; 60 (2):218-24. PMID: 19022533. doi: 10.1016/j.jaad.2008.09.022

2. Globe D, Bayliss MS, Harrison DJ. The impact of itch symptoms in psoriasis: results from physician interviews and patient focus groups. Health and quality of life outcomes. 2009; 7:62. PMID: 19580674. doi: 10.1186/1477-7525-7-62

3. Liu Y, Krueger JG, Bowcock AM. Psoriasis: genetic associations and immune system changes. Genes and immunity. 2007; 8(1):1-12. PMID: 17093502.

4. Davidson A, Diamond B. Autoimmune diseases. The New England journal of medicine. 2001; 345 (5):340-50. PMID: 11484692.

5. Williams JP, Meyers JA. Immune-mediated inflammatory disorders (I.M.I.D.s): the economic and clinical costs. The American journal of managed care. 2002; 8(21 Suppl):S664-81; quiz S82-5. PMID: 12516953.

6. Rabe KF, Hurd S, Anzueto A, Barnes PJ, Buist SA, Calverley P, et al. Global strategy for the diagnosis, management, and prevention of chronic obstructive pulmonary disease: GOLD executive summary. American journal of respiratory and critical care medicine. 2007; 176(6):532-55. PMID: 17507545.

7. Sethi S, Murphy TF. Infection in the pathogenesis and course of chronic obstructive pulmonary disease. The New England journal of medicine. 2008; 359(22):2355-65. PMID: 19038881. doi: 10.1056/ NEJMra0800353

8. Fletcher C, Peto R. The natural history of chronic airflow obstruction. British medical journal. 1977; 1 (6077):1645-8. PMID: 871704.

9. Tuder RM, Petrache I. Pathogenesis of chronic obstructive pulmonary disease. The Journal of Clinical Investigation. 2012; 122(8):2749-55. PMC3408733. doi: 10.1172/JCI60324 PMID: 22850885

10. MacNee W. Oxidants/antioxidants and chronic obstructive pulmonary disease: pathogenesis to therapy. Novartis Foundation symposium. 2001; 234:169-85; discussion 85-8. PMID: 11199095.

11. Chiang YY, Lin HW. Association between psoriasis and chronic obstructive pulmonary disease: a population-based study in Taiwan. Journal of the European Academy of Dermatology and Venereology JEADV. 2012; 26(1):59-65. PMID: 21388457. doi: 10.1111/j.1468-3083.2011.04009.x

12. Al-Mutairi N, Al-Farag S, Al-Mutairi A, Al-Shiltawy M. Comorbidities associated with psoriasis: an experience from the Middle East. The Journal of dermatology. 2010; 37(2):146-55. PMID: 20175849. doi: 10.1111/j.1346-8138.2009.00777.x

13. Wakkee $M$, de Vries $E$, van den Haak $P$, Nijsten $T$. Increased risk of infectious disease requiring hospitalization among patients with psoriasis: A population-based cohort. Journal of the American Academy of Dermatology. 2011; 65(6):1135-44. 10.1016/j. doi: 10.1016/j.jaad.2010.08.036 PMID: 21664719

14. Dreiher J, Weitzman D, Shapiro J, Davidovici B, Cohen AD. Psoriasis and chronic obstructive pulmonary disease: a case-control study. The British journal of dermatology. 2008; 159(4):956-60. PMID: 18637897. doi: 10.1111/j.1365-2133.2008.08749.x

15. Stang A. Critical evaluation of the Newcastle-Ottawa scale for the assessment of the quality of nonrandomized studies in meta-analyses. European journal of epidemiology. 2010; 25(9):603-5. PMID: 20652370. doi: 10.1007/s10654-010-9491-z

16. Stroup DF, Berlin JA, Morton SC, Olkin I, Williamson GD, Rennie D, et al. Meta-analysis of observational studies in epidemiology: a proposal for reporting. Meta-analysis Of Observational Studies in Epidemiology (MOOSE) group. Jama. 2000; 283(15):2008-12. PMID: 10789670.

17. Pearce DJ, Morrison AE, Higgins KB, Crane MM, Balkrishnan R, Fleischer AB Jr., et al. The comorbid state of psoriasis patients in a university dermatology practice. The Journal of dermatological treatment 2005; 16(5-6):319-23. PMID: 16428152. 
18. Robinson D Jr, Hackett M, Wong J, Kimball AB, Cohen R, Bala M. Co-occurrence and comorbidities in patients with immune-mediated inflammatory disorders: an exploration using US healthcare claims data, 2001-2002. Current medical research and opinion. 2006; 22(5):989-1000. PMID: 16709321.

19. Nestle FO, Kaplan DH, Barker J. Psoriasis. The New England journal of medicine. 2009; 361(5):496509. PMID: 19641206. doi: 10.1056/NEJMra0804595

20. Eurlings IM, Dentener MA, Mercken EM, de Cabo R, Bracke KR, Vernooy JH, et al. A comparative study of matrix remodeling in chronic models for COPD; mechanistic insights into the role of TNFalpha. American journal of physiology Lung cellular and molecular physiology. 2014; 307(7):L557-65. PMID: 25106431. doi: 10.1152/ajplung.00116.2014

21. Chung KF, Adcock IM. Multifaceted mechanisms in COPD: inflammation, immunity, and tissue repair and destruction. The European respiratory journal. 2008; 31(6):1334-56. PMID: 18515558. doi: 10. 1183/09031936.00018908

22. Lapperre TS, Postma DS, Gosman MM, Snoeck-Stroband JB, ten Hacken NH, Hiemstra PS, et al Relation between duration of smoking cessation and bronchial inflammation in COPD. Thorax. 2006; 61(2):115-21. PMID: 16055612.

23. Wiczling P, Rosenzweig M, Vaickus L, Jusko WJ. Pharmacokinetics and pharmacodynamics of a chimeric/humanized anti-CD3 monoclonal antibody, otelixizumab (TRX4), in subjects with psoriasis and with type 1 diabetes mellitus. Journal of clinical pharmacology. 2010; 50(5):494-506. PMID: 19934031. doi: $10.1177 / 0091270009349376$

24. Jin $Y$, Wan $Y$, Chen G, Chen L, Zhang MQ, Deng L, et al. Treg/IL-17 ratio and Treg differentiation in patients with COPD. PloS one. 2014; 9(10):e111044. PMID: 25329073. doi: 10.1371/journal.pone. 0111044

25. Hijnen D, Knol EF, Gent YY, Giovannone B, Beijn SJ, Kupper TS, et al. CD8(+) T cells in the lesional skin of atopic dermatitis and psoriasis patients are an important source of IFN-gamma, IL-13, IL-17, and IL-22. The Journal of investigative dermatology. 2013; 133(4):973-9. PMID: 23223131. doi: 10.1038/ jid.2012.456

26. Huang N, Liu L, Wang XZ, Liu D, Yin SY, Yang XD. Association of interleukin (IL)-12 and IL-27 gene polymorphisms with chronic obstructive pulmonary disease in a Chinese population. DNA and cell biology. 2008; 27(9):527-31. PMID: 18554158. doi: 10.1089/dna.2007.0715

27. Zhang L, Cheng Z, Liu W, Wu K. Expression of interleukin (IL)-10, IL-17A and IL-22 in serum and sputum of stable chronic obstructive pulmonary disease patients. Copd. 2013; 10(4):459-65. PMID: 23537276. doi: 10.3109/15412555.2013.770456

28. Flisiak I, Zaniewski P, Chodynicka B. Plasma TGF-beta1, TIMP-1, MMP-1 and IL-18 as a combined biomarker of psoriasis activity. Biomarkers: biochemical indicators of exposure, response, and susceptibility to chemicals. 2008; 13(5):549-56. PMID: 18979644.

29. Kondo S, Yoneta A, Yazawa H, Kamada A, Jimbow K. Downregulation of CXCR-2 but not CXCR-1 expression by human keratinocytes by UVB. Journal of cellular physiology. 2000; 182(3):366-70. PMID: 10653603.

30. Dowlatshahi EA, van der Voort EA, Arends LR, Nijsten T. Markers of systemic inflammation in psoriasis: a systematic review and meta-analysis. The British journal of dermatology. 2013; 169(2):266-82. PMID: 23550658. doi: 10.1111/bjd.12355

31. Singh K, Gatzka M, Peters T, Borkner L, Hainzl A, Wang H, et al. Reduced CD18 levels drive regulatory T cell conversion into Th17 cells in the CD18hypo PL/J mouse model of psoriasis. Journal of immunology (Baltimore, Md: 1950). 2013; 190(6):2544-53. PMID: 23418628.

32. Starodubtseva NL, Sobolev VV, Soboleva AG, Nikolaev AA, Bruskin SA. [Expression of genes for metalloproteinases (MMP-1, MMP-2, MMP-9, and MMP-12) associated with psoriasis]. Genetika. 2011; 47(9):1254-61. Epub 2011/11/29. PMID: 22117411.

33. Ludolph-Hauser $D$, Schubert $C$, Wiedow $O$. Structural changes of human epidermis induced by human leukocyte-derived proteases. Experimental dermatology. 1999; 8(1):46-52. PMID: 10206721.

34. Tabrizi M, Wang B, Lu H, Huang S, Bell G, Schwab G, et al. Population pharmacokinetic evaluation of a fully human IgG monoclonal antibody in patients with inflammatory diseases. Inflammation \& allergy drug targets. 2010; 9(4):229-37. PMID: 20860546.

35. Terricabras E, Benjamim C, Godessart N. Drug discovery and chemokine receptor antagonists: eppur si muove! Autoimmunity Reviews. 2004; 3(7-8):550-6. doi: 10.1016/j.autrev.2004.07.037 PMID: 15546804

36. Wittmann M, Helliwell PS. Phosphodiesterase 4 inhibition in the treatment of psoriasis, psoriatic arthritis and other chronic inflammatory diseases. Dermatology and therapy. 2013; 3(1):1-15. PMID: 23888251. doi: 10.1007/s13555-013-0023-0 
37. Huang Z, Mancini JA. Phosphodiesterase 4 inhibitors for the treatment of asthma and COPD. Current medicinal chemistry. 2006; 13(27):3253-62. PMID: 17168849.

38. Kristensen SL, McInnes IB, Sattar N. Psoriasis, psoriatic arthritis and cardiovascular risk: are we closer to a clinical recommendation? Annals of the rheumatic diseases. 2015; 74(2):321-2. PMID: 25429028. doi: 10.1136/annrheumdis-2014-206617

39. Armstrong AW, Harskamp CT, Dhillon JS, Armstrong EJ. Psoriasis and smoking: a systematic review and meta-analysis. The British journal of dermatology. 2014; 170(2):304-14. PMID: 24117435. doi: 10. 1111/bjd.12670

40. Egger M, Smith GD. Bias in location and selection of studies. BMJ (Clinical research ed). 1998; 316 (7124):61-6. PMID: 9451274.

41. Martin A, Badrick E, Mathur R, Hull S. Effect of ethnicity on the prevalence, severity, and management of COPD in general practice. The British journal of general practice: the journal of the Royal College of General Practitioners. 2012; 62(595):e76-81. PMID: 22520773. 